VIDEO SURGERY TECHNIQUES

\title{
HOW TO HARVEST THE FREE FIBULAR FLAP
}

\author{
Parintosa Atmodiwirjo, Mohamad Rachadian Ramadan ${ }^{1}$, Sara Ester Triatmoko ${ }^{1}$,Nadhira Anindita Ralena ${ }^{2}$
}

1. Reconstructive Microsurgery Section, Division of Plastic Surgery, Faculty of Medicine Universitas Indonesia, dr. Cipto Mangunkusumo National Hospital. Jakarta, Indonesia.

2. Faculty of Medicine, Universitas Indonesia. Jakarta, Indonesia

\begin{abstract}
Summary: Free fibular flap (FFF) is a composite flap consisting of fibular bone and skin paddle. Muscle may be added to the flap. It has several advantages and disadvantages. The fibular free flap is well suited for any reconstruction of the head and neck. It is suitable for defects of the anterior mandibular arch or lateral defects in patients who wish to undergo osseointegrated dental reconstruction. Meanwhile, its contraindications are related with significant atherosclerotic diseases the patient has or congenital variants of the arteries. Preparations for free fibula flap harvesting procedure consist of history taking, physical examinations and supporting examinations, as other free flaps procedure in general. Several intraoperative preparations should also be done.

Keywords: Free Fibula Flap; Microsurgery; Reconstructive Microsurgery, Flaps

Ringkasan: Free fibular flap (FFF) adalah flap komposit yang terdiri dari tulang fibula dan skin paddle. Otot dapat ditambahkan ke flap. FFF memiliki beberapa kelebihan dan kekurangan. Flap ini sangat cocok untuk rekonstruksi kepala dan leher. Flap ini juga sangat cocok untuk defek di lengkung rahang bawah anterior atau defek lateral pada pasien yang ingin menjalani rekonstruksi gigi. Sementara itu, kontraindikasi terkait dengan penyakit aterosklerotik yang signifikan yang pasien miliki atau bawaan kongenital pada arteri. Persiapan untuk prosedur FFF terdiri dari anamnesis, pemeriksaan fisik dan pemeriksaan pendukung, seperti prosedur free flap lainnya secara umum. Beberapa persiapan intraoperatif juga harus dilakukan.

Kata Kunci: Free Fibula Flap; Free flaps; Bedah mikro; Bedah mikro rekonstruksi
\end{abstract}

Conflicts of Interest Statement:

The author(s) listed in this manuscript declare the absence of any conflict of interest on the subject matter or materials discussed.

\section{SUPPORTING INFORMATION}

This is Video Article, additional supporting information may be found online on the JPRjournal Official YouTube channel: https://youtu.be/237tbvHKQY4 


\section{INTRODUCTION}

Free Fibula flap (FFF) is a composite flap consisting of fibular bone and skin paddle. Additionally, muscle may be also added with the FFF. The FFF has several advantages. This flap provides a vascularized long bone and versatility of skin paddle for defect closure, compared to other osteoseptocutanoeus flap (iliac crest or scapular osteocutaneous flap). It allows multiple osteotomies due to dedicated vascular supply from endosteal and periosteal. This flap provides large vessels for anastomosis especially for head and neck area. Patients undergoes bony reconstruction with FFF also have lower chance in to get additional reconstruction for disability in the donor site. This is due to acceptable loss of peroneal artery and concomitant vein.1,2,3

However, the FFF has several disadvantages: this flap mostly requires skin graft, has less desirable scar and may cause limitations and noticeable dysfunction at the donor site leading in discomfort. ${ }^{1}$

\section{INDICATIONS}

The fibular free flap is well suited for any reconstruction of the head and neck. It is suitable for defects of the anterior mandibular arch or lateral defects in patients who wish to undergo osseointegrated dental reconstruction. Its indications include oncologic resections, traumatic injuries, and osteoradionecrosis. ${ }^{4}$

\section{CONTRAINDICATIONS}

Meanwhile, this procedure has several contraindications as well. They include significant atherosclerotic disease in the abdominal aorta, iliac or femoral arteries, or popliteal artery, prior major trauma to the limb, and congenital variants of arteries. ${ }^{5}$

\section{PREPARATIONS}

Preparations for FFF harvesting procedure consist of history taking, physical examinations and supporting examinations, as other free flaps procedure in general. ${ }^{1}$

Identification of peripheral vascular disease, deep vein thrombosis, venous stasis disease, arteritis, congenital bone anomaly, and previous surgery and trauma in donor area should be identified in history taking. ${ }^{1}$
Physical examinations should include examination of range of motion and laxity of the knee and ankle and foot Allen's test with Doppler to measure the dorsal pedis and posterior tibial artery. ${ }^{1}$ Supporting examinations may include CT-angiography, especially in patients with history of trauma in the donor area or peripheral vascular disease, and ultrasonography.

Several steps of intraoperative preparations should be conducted. First, appropriate side of fibula in regards to the skin paddle's position towards the defect, as well as the pedicle's position on the prepared recipient, should be determined. IV line should not be attached in the surrounding of the fibula.

Tourniquet should be prepared and installed proximally to the fibula. Then drape the patient with exposure from knee to tip of toe. Draping should be loose enough to allow knee flexion and internal rotation of the hip at the prepared fibula site. After that, mark the anatomic landmark on the fibula in the form of a line $6 \mathrm{~cm}$ below the fibula head as the superior landmark of the flap design (to prevent injury to peroneal nerve), while the inferior landmark is of $6 \mathrm{~cm}$ above the lateral malleolus (to keep ankle stabilisation). Then, decide the cutaneous perforator's position, which normally located at the posterior border of the fibula, approximately, between the $1 / 3$ middle to $1 / 3$ distal. Confirm the location with a handheld sound Doppler. ${ }^{1}$

Exsanguination (lift up to 45 degree) of the leg for about 5-10 minutes should be performed and inflate the tourniquet while the leg is still elevated, $300 \mathrm{mmHg}$ for adult (adjust the cuff according to patient's thigh diameter) 200 $\mathrm{mmHg}$ for pediatric patients. Regarding time setting, set the time for maybe 90 minutes. Finally, keep patient in supine position with knee flexed for 90 degree. Hip is internally rotated while the foot sole is fixed on the table. ${ }^{1}$

\section{SUMMARY}

Free fibular flap (FFF) is a composite flap consisting of fibular bone and skin paddle. Indications and contraindications should be determined before procedure through history taking, physical examinations and supporting examinations. 
Correspondence regarding this article should be addressed to:

Parintosa Atmodiwirjo, MD.

Reconstructive Microsurgery Section, Division of Plastic

Surgery, Dr. Cipto Mangunkusumo National Hospital, Universitas Indonesia. Jakarta 12310, Indonesia.

E-Mail: parintosa.atmodiwirjo@ui.ac.id

\section{REFERENCES}

1. Atmodiwirjo P, Triatmoko SE. How To Harvest The Free Osteoseptocutaneous Fibular Flap: Step-by-Step. Jakarta: Lingkar Studi Bedah Plastik; 2019

2. Atmodiwirjo P. Early And Recent Development Of Reconstructive Microsurgery Subspeciality In Dr. Cipto Mangunkusumo National Hospital,
Universitas Indonesia (1983-2020). Jurnal Plastik Rekonstruksi. 2020;6(2):281-90.

3. Atmodiwirjo P, Putri N. The Advantages of Vascularized Fibular Bone Graft For Mandibular Tumor Reconstruction. Jurnal Plastik Rekonstruksi. 1970;1(1).

4. Kokosis G, Schmitz R, Powers DB, Erdmann D. Mandibular Reconstruction Using the Free Vascularized Fibula Graft: An Overview of Different Modifications. Arch Plast Surg. 2016;43(1):3-9.

5. Aine M. Kelly, Paul Cronin, Hero K. Hussain, Frank J. Londy, Douglas B. Chepeha, and Ruth C. Carlos. Preoperative mr angiography in free fibula flap transfer for head and neck cancer: Clinical application and influence on surgical decision making. American Journal of Roentgenology. 2007;188: 268-274. 